This page intentionally left blank 


\section{THE CHRISTIAN}

\section{IMAGINATION}

Theology and the Origins of Race

Willie James Jennings

\section{Yale}

UNIVERSITY PRESS

New Haven \& London 


\section{Copyright (@) 2010 by Yale University. \\ All rights reserved.}

This book may not be reproduced, in whole or in part, including illustrations, in any form (beyond that copying permitted by Sections 107 and 108 of the U.S. Copyright Law and except by reviewers for the public press), without written permission from the publishers.

Set in Electra and Trajan types by Tseng Information Systems, Inc., Printed in the United States of America by Sheridan Books, Ann Arbor, Michigan.

\section{Library of Congress Cataloging-in-Publication Data}

Jennings, Willie James, 1961-

The Christian imagination : theology and the origins of race / Willie James Jennings.

$$
\text { p. } \mathrm{cm} \text {. }
$$

Includes bibliographical references (p. ) and index.

ISBN 978-0-300-15211-1 (hardcover : alk. paper)

1. Race-Religious aspects-Christianity. I. Title.

$$
\begin{gathered}
\text { BT734.2.J46 } 2010 \\
270.089-\mathrm{dc} 22 \\
2009040203
\end{gathered}
$$

A catalogue record for this book is available from the British Library.

This paper meets the requirements of ANSI/NISO Z39.48-1992 (Permanence of Paper).

$$
\begin{array}{llllllllll}
10 & 9 & 8 & 7 & 6 & 5 & 4 & 3 & 2 & 1
\end{array}
$$


For Mary and Ivory, who while they picked cotton, feet touching the soil, dreamed of a different world 
This page intentionally left blank 